\title{
Saintifik dengan bermain air warna di TK Aisyiyah Bustanul Atfal Kajai Kabupaten Pasaman Barat
}

\author{
Sastra Sofia \\ Universitas Negeri Padang
}

\begin{abstract}
This study used Classroom Action Research conducted in Kindergarten Aisyiyah Bustanul Atfal Kajai. This research was conducted for 2 months, namely as many as 2 cycles, namely cycle I consisted of 3 meetings and cycle II consisted of 3 meetings. Data collection with observation, interviews, and documentation were analyzed by percentage techniques. The results of observations in the initial conditions showed that children's scientific abilities were still low. The implementation of the first cycle of the first meeting to the third shows an increase in children's scientific abilities, but has not yet reached the KKM so that the second cycle is carried out. After the second cycle, the first meeting until the third meeting saw a significant increase in children's scientific abilities, especially in terms of children's abilities. Based on these studies it can be concluded that there is an increase in children's scientific abilities through the Science approach by playing Color Water at Aisyiyah Bustanul Atfal Kajai Kindergarten, Regency of West Pasaman.
\end{abstract}

Keywords: Science ability, scientific improvement

This is an open access article distributed under the Creative Commons Attribution License, which permits unrestricted use,
distribution, and reproduction in any medium, provided the original work is properly cited. @ 2018 by author

\section{PENDAHULUAN}

Taman Kanak-Kanak merupakan suatulembaga pendidikanyang berada dalam jalur formal dan berfungsi sebagai penyelenggara pendidikan dan upaya mempersiapkananak untuk melanjutkan ke Sekolah Dasar( SD ). Kegiatan di Taman Kanak-kanak sangat berbeda dengan kegiatan pembelajaran di Sekolah Dasar. Pendidikan Taman Kanak-kanak mengupayakan program pengembangan perilaku / pembiasaan dan pengembangan kemampuan dasar. Pengembangan kemampuan dasarmeliputi bahasa, kognitif, fisik/ motorik danseni, kemampuan dasar merupakan kegiatan yangdipersiapkan oleh guru untuk meningkatkan kemampuan dan kemampuan sains sesuai dengantahap perkembangan anak.

Salah satulangkah yangsignifikandanstrategi untuk dapat memberikanperbekalan yang optimalpada anak adalah didahuluidengan memahami karakreristik dantujuan pendidikan dan pembelajaran yangakan direrapkan pada anak usia dini, termasuk dalam bidang pengembangan pembelajaran sains untuk anak. Pemahaman dan penguasaan akan tujuan dalam penguasaan program pembelajaran sains untuk anak usia dini yang dianggap tepat.

Pengembanganpembelajaran sains anak usia dini memupuk rasa ingin tahu tentang sesuatu yang diamatinya. Rasa ingin tahu rersebut perlu difasilitasi oleh pendidik. Anak dapat belajar apa saja asal tidak dipaksakan, terutama belajar sains sejak dini.Belajar sains sejak dini dimulai dengan memperkenalkanalam dengan melibatkan lingkungan untuk memperkaya pengalaman anak.

Pembelajaran dalam kurikulm 2013 ada yang disebut dengan pembelajaran pendekatansaintifik. Pendekatan saintifik ini merujukpada teknik-teknik investigasi atas Fenomena atau gejala,memperoleh pengetahuan baru, atau mengoreksi dan memadukan pengetahuansebelumnya.Penerapan saintifik dalam pembelajaran melibatkan keterampilan proses seperti rnengamati. Mengklasifikasikan, mengukur, 
merarnalkan, rnenjelaskan dan menyimpulkan.Pendekatanilmiah dalam pembelajaran sebagaimana dimaksud meliputi mengamati, menanva, rnenalar,mencoba, dan membentuk jaringan.

Sudono dalam Cucu (2005) menyatakan bahwa memanfaatkan lingkungan sebagai sumber belajar dapat memberi masukan dan informasi maupun pengertian pada anak. Anak akan belajar bereksperimen, bereksplorasi dan menginvestasi lingkungan disekitarnya sehingga anak mampu membangun sesuatu pengetahuan yang nantinya dapat digunakan setelah dewasa. Menurut Slamet (2005) Kemampuan sains untuk anak TK adalah (1) mengobservasi benda, (2) mengklasifikasikan benda, (3) Pengukuran terhadap benda, (4) menyimpulkan benda yang diamati, dan (5) mengkomunikasikan benda yang diamati.

Tho (2008) menjelaskan bahwa, Sains adalah sebuah system mengenal alam serta pengaruhnya terhadap manusia dan lingkungannya. Sains merupakan ilmu pengetahuan yang selalu akan berobah sesuai dengan perkembangan alat penelitinya. Dengan kemajuan yang cepat dalam sains, standard hidup kita meningkat.

Amian dalam Nasution (1987) Sains sebagai bidang ilmu alamiah, dengan ruang lingkup zat dan energi baik yang terdapat dalam makhluk hidup maupun yang tidak dalam makhluk hidup. Sedangkan menurut Kemusia dalam Patmodewo (2000) mengartikan sains sebagai suatu kemampuan pengetahuan yang diperoleh dengan menggunakan metode-metode yang berdasarkan kepada pengamatan dan penuh penelitian.

Berdasarkan pengamatan yang peneliti temui diapangan, tepatnya dalam proses pembelajaran di taman kanak - kanak aisyiah bustanul atfal kajai. Dalam pelaksanaan kegiatan belum berkembangnya kemampuan sains anak seperti belum dapat menunjukkan aktivitas yang bersifat eksploratif dan menyidik. Hal ini disebabkan kurangnya alat / media dalam pengembanga sain anak.

Berdasarkan latar belakang masalah, maka dapat didefenisikan permasalahan yang muncul dalam peningkatan kemampuan sains anak adalah kurang berkembangnya kemampuan sains anak, kurangnya alat/media pembelajaran dalam pengembangan sains anak.

Penelitian yang dilakukan dalam kegiatan ini adalah penelitian tindakan kelas. Menurut Arikunto (2007) bahwa penelitian tindakan kelas adalah penelitian yang dilakukan guru bekerjasama dengan peneliti atau melakukan dengan sendiri yang juga bertindak sebagai peneliti dikelas tempat peneliti mengajar dengan penekanan dan penyempurnaan peningkatan proses belajar.

Tujuan penelitian ini adalah untuk peningkatan kemampuan anak dalam sains di taman kanak - kanak aisyiah bustanul atfal Pasaman Barat.Manfaat yang diambil dari peningkatan kemampuan sains anak adalah bagi anak didik dapat meningkatkan kemampuan sainsnya, menambah wawasan dan pengalaman dalam membantu guru memperbaiki pembelajaran, dapat meningkatkan kualitas anak, sebagai pusat peningkatan kualitas pelayanan dalam meningkatkan dimensi - dimensi perkembangan di taman kanak - kanak.

\section{METODE}

Penelitian ini berbentuk penelitian tindakan kelas (Class Room Action Research), (Arikunto, 2006) untuk dapat melalkukan penelitian tindakan kelas ini guru hendaknya memahami berbagai permasalahan yang ditemui dikelas sehari-hari yang ditemui di dalam proses belajar mengajar di Taman Kanak-Kanak Aisyiyah Bustanul Atfal Kajai.

Bentuk penelitian yang dilakukan adalah dengan menggunakan pendekatan kualitatif. Penelinan inibertujuan untuk meningkatkan kemampuan sainsmelalui pendekatan sainstifik bermain air wama berjalan.Penelitian ini dilakukan pada semester ganjil 2018/ 2019di Taman Kanak-Kanak Aisiyah Bustanul Atfal Kajai.

Subjek penelitian yang peneliti gunakan dalam penelitian ini adalah Taman Kanak-Kanak Aisyiyah Bustanul Atfal Kajai. Yang terdiri dari kelas B1, B2 dan B3, tetapi peneliti memilih untuk meneliti di kelas B1yang berjumlah 15 orang dengan rincian 6 orang anak perempuan dan 9 orang anaklaki-laki. Adapun alasan penclitian di kelas B1 karena peneliti mengajar di kelas tersebut.

Prosedur pelaksanaan penelitian akan dilakukan secara bersiklus yang dimulaidari siklus pertama, dilaksanakan 3 kali pertemuan bila belum berhasil disiklus I maka dilanjutkan ke sklus kedua. Sikluskedua sangat ditentukan oleh hasil refleksi Arikunto (2006) siklus pertama terdiri dari kegiatan perencanaan, pelaksanaan, observasi dan refleksi. 


\section{HASIL}

Berdasarkan pelaksanaan pada siklus I pertemuan pertama, kedua dan ketiga, maka peneliti mendapatkan nilai masing - masing aspek yang dinilai pada pertemuan I hanya $0 \%$ meningkat menjadi $12,5 \%$ pada pertemuan ketiga. Hal ini menunjukkan bahwa terdapat peningkatan kemampuan sosial anak setelah dilakukan siklus I pertemuan pertama, kedua dan ketiga.

Setelahdilakukan siklus II, diketahui aspek pertamaanak mampu mengklasifkasikan benda berdasarkan warna, pada pertemuan ketiga diketahui $93,5 \%$ anak berkembang sangat baik dan 6,25\%. Aspek kedua, anak mampu mengurutkan lima seriasi atau lebih berdasarkan warna mengalami peningkatan. Pada akhir siklus II pertemuan ketiga didapatkan hasil bahwa anak yang mendapatkan nilai berkembang sangat baik $81,25 \%$. Aspek ketiga, anak mencobakan cara pencampuran warna didapatkan hasil $75 \%$ anak mendapatkan nilai berkembang sangat baik dan $25 \%$. Kemampuan anak yang mendapatkan nilai berkembang sangat baik (BSB) dapat dilihat pada tabel berikut ini :

Tabel 1.

Hasil Observasi Peningkatan Kemampuan Sains Melalui Pendekatan Saintifik dengan Bermain Air Warna

\begin{tabular}{clccc}
\hline No & \multicolumn{1}{c}{ Aspek yang dinilai } & $\begin{array}{c}\text { Kondisi awal } \\
(\boldsymbol{\%})\end{array}$ & $\begin{array}{c}\text { Siklus I } \\
(\boldsymbol{\%})\end{array}$ & $\begin{array}{c}\text { Siklus II } \\
(\boldsymbol{\%})\end{array}$ \\
\hline 1 & $\begin{array}{l}\text { Anak mampu } \\
\text { mengklasifikasikan benda } \\
\text { berdasarkan warna } \\
\text { Anak mampu mengurutkan lima } \\
\text { seriasi atau lebih berdasarkan } \\
\text { warna }\end{array}$ & 0 & 12,5 & 93,75 \\
2 & $\begin{array}{l}\text { Anak menemukan berbagai cara } \\
\text { pencampuran warna }\end{array}$ & 0 & 18,75 & 87,5 \\
& & 0 & 12,5 & 81,25 \\
\hline
\end{tabular}

Hasil kondisi awal pada penelitin ini diketahui bahwa pada aspek pertama anak mampumengklasifikasikan benda berdasarkan warna yang mendapat nilai berkembang sangat baik sebesar $0 \%$. Keadaan ini meningkat pada siklus I yaitu 12,5\% dan meningkat pada siklus II menjadi 93,75\%. Aspek kedua anak mampu mengurutkan lima serasi warna atau lebih berdasarkan warna pada kondisi awal tidak ada yang mendapatkan nilai berkembang sangat baik atau 0\%, meningkat disiklus I menjadi 18,75\% dan meningkat menjadi 87,5\% pada siklus II. Aspek ketiga anak menemukan berbagai cara pencampuran warna pada kondisi awal tidak ada yang mendapatkan nilai berkembang sangat baik, meningkat menjadi $12,5 \%$ pada siklus I dan meningkat menjadi $81,25 \%$ pada siklus II.

\section{PEMBAHASAN}

Berdasarkan hasil penelitian, kemampuan sains anak dapat meningkat dengan melakukan kegiatan bermain dengan air warna secara bersama-sama. Dalam permainan air warna anak dibagi dalam beberapa kelompok dan anak akan diobservasi selama proses permainan dengan air warna tersebut. Aspek yang diamati adalah anak mampu mengklasifikasikan, anak mampu mengurutkan lima seriasi atau lebih, dan anak menemukan berbagai cara pencampuran warna.

Berdasarkan hasil refleksi, maka peneliti membuat siklus II karena masih ada anak yang memiliki kemampuan belum berkembang (BB). Peningkatan kemampuan sains anak paling besar terlihat pada aspek pertama, aspek kedua dan aspek ketiga. Berdasarkan hasil observasi peneliti pada aspek pertama, anak mampu mengklasifikasikan benda berdasarkan warna, anak mampu mengurutkan lima seriasi atau lebih berdasarkan warna, dan anak menemukan berbagai cara pencampuran warna bahwa terjadi peningkatan kemampuan sains seiring dengan intensitas kegiatan yang dilakukan. Pendekatan oleh guru merupakan faktor penting anak untuk mendorong dan memotivasi anak dalam mengembangkan kemampuan dan kemauannya.

Aspek pertama, anak mampu mengklasifikasikan benda berdasarkan warna, pada pertemuan ke tiga diketahui 93,75\%, anak berkembang sangat baik dan 6,25\% anak berkembang sesuai harapan. Aspek kedua, yaitu anak mampu mengurutkan lima seriasi atau lebih, dalam permainan air warna, anak saling membantu dan mengingatkan langkah-langkah yang harus dilakukan selama proses permainan dengan air warna berjalan. Pada akhir siklus II pertemuan ketiga didapatkan hasil bahwa anak yang mendapatkan nilai berkembang sangat baik 81,25 , dan $18,75 \%$ berkembang sesuai harapan. Aspek ketiga, anak menemukan berbagai cara pencampuran 
warna didapatkan hasil $75 \%$ anak mendapatkan nilai berkembang sangat baik dan $25 \%$ anak berkembang sesuai harapan. Peningkatan kemampuan sains pada aspek ini terlihat pada keinginan anak untuk segera merapikan peralatan yang digunakan adalam permainan air warna berjalan.

Hasil dari penelitian ini bahwa pendekatan saintifik dengan bermain air warna dimana anak dapat mencobakan langsung dan mengamati apa yang dilakukannya dalam proses bermain air warna. Menurut $\mathrm{M}$. Lazim bahwa pendekatan saintifik merupakan proses pembelajaran yang dirancang sedemikian rupa agar peserta didik secara aktif mengonstruk konsep, hukum atau prinsip melalui tahapan - tahapan mengamati, merumuskan masalah, mengumpulkan data, menganalisis data, menarik kesimpulan dan mengomunikasikan.

\section{KESIMPULAN}

Penelitian tindakan kelas tentang peningkatan kemampuan sains melalui pendekatan saintifik dengan bermain air warna berjalan yang telah dilaksanakan di TK Aisyah Bustanul Atfal Kajai, dapat disimpulkan sebagai berikut:Terdapat peningkatan kemampuan sains anak dalam pendekatan Saintifi dengan bermain dengan air warna berjalan dengan menilai aspek kemampuan anak mengklasifikasikan benda, mengurutkan lima seriasi atau lebih berdasarkan warna, dan menemukan berbagai cara pencampuran warna.Hasil yang diperoleh aspek 1 diketahui baahwa pada kondisi awal terdapat $75 \%$.

\section{DAFTAR PUSTAKA}

Aisyah, Siti. (2007). Pembelojaran dan Konsep Dosor Pengembangan Anak Usia Dini. Jakarta: Universitas Negeri Jakarta

Ali Nugraha. (2005). Pengembangan PembelajoranSains Pada PAUD. Jakarta:Depdiknas.

Anwar, AhmadArsyad. (2009). Pendidikan Anak Usia Dini. Bandung: Alfabeta

Arikunto, Suharsimi. (2006). Penelitian Tindakan Kelas. Jakarta: PT. Bumi Aksara

Arsyad, Azhar . (2011). Media Pembelajaran. Jakarta: PT Raja Grafindo Persada

Arief S Sadiman, dkk. (2006). Media Pembelajaran. Jakarta : PT Raja Grafindo Persada

Cucu, Elyawati. (2005). Pemilihan dan PengembanganSumber Beiaior Anak. Usia Dini. Jakarta.Depdiknas

Darmansyah, (2009). PenelitianTindakonKelas. Padang Universitas NegeriPadang

Depdiknas, Dirjen Pendidikan Dasar dan Menengah Direktorat TenagaKependidikan. (2003). PenelitianTindakonKelas.Jakarta

Harlock. (1980). PerkembongonAnak Jilid I edisiEnama. Jakarta: Erlangga

Hartati, Sofia. (2005). Pengembangan Belajar padaAnak Usia Dini. Jakarta:Rineka Cipta

Hudoyono, Herman. Media Pembelajaran. Jakarta: PT Raja Grafindo Persada

Kate Scarborough. (2008). Sains dan Percobaan llmiah Untuk Anak Cerdas.

Yogyakarta: Gala Ilmu Semesta

Montolalu, BEF, dkk. (2005). Bermain Dan Permainan Anak. Jakarta: UniversitasTerbuka

Musfiro, Tadkiroatun. (2005). Bermam Dan Mengasah Kecerdasan. Jakarta: Depdiknas

Semiawan, Conny. (2009). Konsep Dasar Pendidikan Anak Usia Dini. Jakarta:Indeks

Soefandi, Indra. (2009). Strategi Pengembangan Potensi Kecerdasan Anak. Jakarta:Bee Media Indonesia

Sujiono, Yuliani, Nurani. (2009). Konsep Dasar Pendidikan Anak Usia Dini.Jakarta: Indeks

Suyanto, Slamet. (2005. Konsep Dasar Pendidikan Anak Usia Dini. Jakarta: Departemen Pendidikan Nasional

Tedjasaputra. (2001). Bermain, Mainan dan permainan. Jakarta: Gramedia Widyaswarana indonesiaTho lai Hoong. 2008. Sains. Jakarta: Erlangga

Wijaya Kusuma. (2009). Mengenal Penelitian Tindakan Kelas.Jakarta. Malta Pritindo 